\title{
Capital Market Response to the Change in the Dividend Policy: The Case of Slovenian Stock Market
}

\author{
Matjaž Mikluš ${ }^{1} \&$ Žan Jan Oplotnik ${ }^{2, *}$ \\ ${ }^{1}$ Raiffeisen Banka d.d. Zagrebška cesta 76, 2000 Maribor, Slovenia \\ ${ }^{2}$ Faculty of Economics and Business, University of Maribor, Razlagova 14, 2000 Maribor, \\ Slovenia \\ *Corresponding author: Faculty of Economics and Business, University of Maribor, \\ Razlagova 14, 2000 Maribor, Slovenia. Tel: 386-40-247-866 E-mail: zan.oplotnik@um.si
}

Received: January 9, 2016 Accepted: February 17, 2016 Published: March 24, 2016

doi:10.5296/rae.v8i1.8839 URL: http://dx.doi.org/10.5296/rae.v8i1.8839

\begin{abstract}
The three basic dividend policy theories have a completely different approach to describing the influence of dividends payment on stock price, and on the value of the company. Numerous studies conducted in this area have led to almost as many derived dividend policy theories, which are more or less related to the basic three. As one of them Wang, Manry \& Wandler (2011) specify the dividend signalling theory, which is based particularly on the assumption of the asymmetry of information between the company management and the shareholders and in recent decades it has been studied by many authors, who mostly concluded that dividend increase has a positive stock price reaction, and vice versa, that dividend decrease results in stock price falls (as cited in Ross, 1977; Leland and Pyle, 1977; Grinblatt et al., 1984; Baker and Phillips, 1993; Rankine and Stice, 1997; Bechmann and Raaballe, 2007). For the purposes of our analysis we adopted the methodology of foreign researches and checked the existence of the dividend signalling theory in the Slovenian stock market. The Slovenian stock market is one of developing markets, and is particularly specific due to its small size and illiquidity. Our research resulted in no statistically significant stock price increases from company dividend increases, whereby we have refuted the research hypothesis and, consequently, the dividend signalling theory in the Slovenian stock market in the described period.
\end{abstract}

Keywords: dividend policy, dividend signalling theory, stock price reaction, financial market, Slovenian stock market

JEL: G10, G14, G30, G35 


\section{Introduction with an Overview of Literature}

Dividends are distribution of company profit of the current year or previous years among owners. Dividend policy was and still is the subject of numerous researches, in which the results often contradict each other. So, there is still no universally adopted opinion about the influence of dividend payment on the company's market value and thus the value of shareholders' assets. The decision on appropriate dividend policy is very important, because shareholders can increase their assets in two ways, i.e. by capital gains, and by cash or non-cash dividends. As we can see, the dividend policy decision may have a direct influence on the value of shareholders' assets. According to Brigham and Ehrhardt (2002) in 1961, Miller and Modigliani introduced the dividend irrelevance theory, which maintains that it is completely irrelevant whether the company pays out dividends or not, and to what proportion, because this will have no stock price reaction. They further argued that company profitability is the only thing that matters to shareholders and not whether they gain profit in the form of dividend or in the form of capital gains. Because their theory is structured on very non-realistic assumptions about a perfect capital market, other theories soon gained ground, which discuss the dividend policy in a different light and attribute a different meaning to it. Two other basic theoretical aspects regarding the relevance of dividend policy appeared; bird-in-the-hand theory and tax preference theory. Advocates of the bird-in-the-hand theory claim that investors are more inclined to immediate return from dividend payments than to the reinvestment of profit and less certain returns in the future. According to this theory, the stock prices of companies, which pay lower dividends or do not pay them at all, will drop due to sales pressure, because investors will sell these stocks and trade them with stocks of companies that pay out higher dividends. Advocates of the tax preference theory claim quite the opposite. According to them, investors are more inclined to capital gains than to dividend payments. The reasons for this originate primarily from the fact that shareholders must immediately settle dividend tax, while the payment of tax on capital gains is postponed to the future, when capital gains will actually be realised. In addition to three basic theoretical aspects on dividend policy, numerous practical dividend payout models and derived theories also appeared. One of the derived theories is the dividend signalling theory, which in a way supports the bird-in-the-hand theory, but it interprets its positive influence in a slightly different way. It is based primarily on the assumption of the asymmetry of information between the company management and shareholders or other investors. The company management should have better information about present and future operations of the company than investors. According to the dividend signalling theory, the company stock price is expected to grow after dividend increase announcement, because a higher dividend gives investors the information about the current situation in the company and about the expectations the company management has about the future. A higher dividend thus gives investors a positive signal about company's operations and, consequently, influences the stock price increase.

Numerous authors, such as Gurgul, Mestel \& Schleicher (2003), Capstaff, Klaeboe \& Marshall (2004), Ben Arab, Ben Sedrine \& Karaa (2004), McClusky et al., (2006), Akbar \& Baig (2010), Taneem \& Yuce (2011), Gupta et al. (2012), empirically analysed the influence of the management's dividend increase announcements on stock prices and confirmed the 
existence of the dividend signalling theory in developed markets as well as in developing markets. Because, according to our information, a similar research has not yet been conducted for the Slovenian market, we decided to use the recommended methodology of research and examine whether the management's dividend increase announcement in the Slovenian stock market has a positive influence on stock prices, i.e. whether the dividend signalling theory holds for the Slovenian stock market. The Slovenian stock market is very specific for a number of factors. It is one of the developing markets is rather undeveloped and also inefficient, particularly due to its short history and small size. One of the main problems is market illiquidity, which aggravates similar patterns of behaviour of stock prices, which apply in the most developed markets in the world.

The effect of signalling or reactions of investors to dividend increase have been researched by many authors. Gurgul, Mestel \& Schleicher (2003) examined the stock market response on dividend announcements in Austria. Their pattern includes 22 companies of the ATX index between 1992 and 2002. As opposed to some other authors, who chose the day, when the general meeting confirmed a certain dividend, as announcement date, they defined announcement date as the day on which the management delivered official statement regarding dividend payout for the first time. The findings of the researches of the Austrian market showed a strong support to the hypothesis, which says that announcement of a future dividend has an important influence on the behaviour of investors. They examined three sets of responses of investors, i.e. the response on dividend increase, response on dividend reduction, and response on the event, when the dividends remain unchanged. Further, they also observed the proportion of trade in individual stocks around the dividend announcement date and stock volatility in this period. They came to establish that dividend increase has a strong influence on stock price, while the reduction in dividends, inversely, causes a sharp drop of stock price. Unchanged dividends don't have an important influence on stock price in the negative or positive direction. Gurgul, Mestel \& Schleicher (2003) further established that the news on new dividends quickly reflect in the new stock price and that around the announcement date the trade in stocks of the company, whose management proposed higher dividend, also statistically significantly increases. They explain this by reasoning that investors perceive new information in a different way and this leads to increased trade in this period. Ben Arab, Ben Sedrine \& Karaa (2004) carried out a similar research as others in the Tunisian stock market. Following the example of others, this research also included a study of the event within a time slot of the event by applying the market model. They assumed complete efficiency of the capital market and the fact that the news, either good or bad, will immediately reflect in the changed stock price. The pattern was composed of 124 events, i.e. dividend announcement of 35 companies between 1998 and 2001. The results of the research showed that Tunisian stocks also positively react to the dividend increase announcement and thus support the presence of the dividend signalling theory in the Tunisian stock market. Even on the long term, the stock price moves in the direction of the movement of dividends. The dividend signalling theory was also studied by Capstaff, Klaeboe \& Marshall (2004), who chose the Norwegian stock exchange as their research subject. Norway is an interesting environment due to the company ownership structure. The structure of equity capital in Norway is much less dispersed than in USA or Great Britain, because the largest three 
shareholders in Norwegian companies were, on average, the owners of $41 \%$ of all company stocks (USA 25\%, England 21\%). The more profit is intended for dividend payout, the more often the company management will have to turn to external sources of capital, if they lack capital for investments, and the more often they will be subject to thorough external control. Norwegian companies supposedly have lower costs of brokers, because large owners are more attentive when it comes to the control of their investments, which means there is less need for the use of dividends as the tool for the reduction of such costs. Authors analysed 64 Norwegian companies in the period between 1993 and 1998. In this period the researchers analysed 156 dividend payout announcements. The data were classified into three sets with regard to whether the company increased the dividend, reduced it or kept it at the same level. As regards dividend increase and dividend decrease, exceptional growth or drop of stock price was recorded. It was further established that the higher the dividend increase, the stronger the market reaction, and vice versa. The strongest market reactions follow dividend increase announcements, which are followed by long-term increase of cash flow of the company. This supports the dividend signalling theory.

Akbar \& Baig (2010) explored the medium-strong efficiency of the Pakistani stock market, through the influence of dividend announcements on stock prices in the Pakistani market. A particular feature here is that they analysed each type of the remuneration of shareholders separately; at first only cash dividends, then stock dividends, and, finally, the effect of cash dividends and stock dividends together. The data contained 193 dividend payout announcements by 79 companies in the period between 2004 and 2007. The results didn't show any statistically significant positive reactions upon cash dividend announcement, in fact, reactions were mostly negative. This could, according to the authors, be attributed to poorer tax treatment of dividends with regard to capital gains. But the results have shown statistically significant increase in stock prices upon the stock dividend announcement. This could be attributed to the fact that stock dividends are not subject to tax there, and the same applies to capital gains, which clearly also indicates greater inclination of investors to capital gains.

Taneem \& Yuce (2011) analyse the effect of dividend signalling in the Indian stock market. They discuss that even though the companies are not obliged to pay out dividends, the majority of companies still chooses some kind of dividend policy. The reason for this, according to the authors, is particularly the effect of dividend signalling, i.e. that the company uses dividends as the method of communicating with investors. The authors analysed 82 companies from various industries in the period between 2004 and 2007. The analysis showed that stock prices in the Indian market react positively to dividend increase and negatively to dividend decrease. The results led them to conclude that dividend increase carries certain information about good prospects in the future and can by itself statistically significantly increase stock price. In general, the research firmly supported the signalling effect theory in the Mumbai market. Also Gupta et al. (2012) explored stock price reactions on dividend announcements in the Indian market. The sample comprises of 28 companies, which are listed in the BSE 30 Sensex index, and the researchers analysed only those events, where the companies decided to increase their dividends between 2006 and 2009, whereby 65 
events were analysed. The market model was used for determining whether statistically significant abnormal returns appear around the dividend increase announcement date. This article proves that the better the information about a certain company the market has, the smaller the reaction to new announcements, and less the information the market has, the more impatiently it expects new announcements in the form of dividends. The authors showed statistically significant positive influences on the announcement date. As opposed to the majority of others, this one showed that the stock prices reacted stronger to dividend increase than to dividend decrease. This could mean that negative news reflects in stock price long before the announcement, and the stock only slightly changes upon actual announcement (Gupta et.al, 2012).

\section{Research Objectives, Hypotheses and Methodology}

Review of literature showed that in the majority of markets, developed and developing markets, stock prices positively react to dividend increase announcements. In this research we are analysing stocks of the Slovenian blue chip index SBI TOP between 2008 and 2012. The purpose is to determine stock price reaction to proposed dividend increases by the company management, and thus either confirm or refute the presence of the dividend signalling theory in the Slovenian stock market. We want: to explore the role and the influence of dividend increases on stock prices, check the existence of the dividend signalling theory in the Slovenian stock market, analyse the trend in stock prices within a time slot around the announcement date, and compare the results acquired in the Slovenian market to the ones abroad. In order to be able to check the above objectives empirically, we have to form null hypotheses. If we want to confirm the existence of the dividend signalling theory, abnormal returns within a time slot $(\mathrm{t}=0, \mathrm{t}=+1)$ would have to be statistically significantly different from zero (according to McClusky et al., 2006).

Hypothesis 1: $\boldsymbol{H O}_{\mathbf{1}}$ : Dividend increase announcements of Slovenian stock companies do not have a statistically significant influence on stock prices. Hypothesis 2: $\mathbf{H O}_{2}$ : Dividend increase announcements of Slovenian stock companies in the periods of fall of the Slovenian stock index do not have a statistically significant influence on stock prices.

The data were obtained from official websites of companies, the Ljubljana Stock Exchange website, and the Ljubljana Stock Exchange portal SEOnet. In this research we are focused on analysing the effects of predicted dividend increase announcements on stock prices. The Slovenian market is very specific due to its small size and illiquidity, so our sample includes companies from the SBI TOP index, which is composed of the "best" and particularly the most liquid stocks. The index is composed of 9 companies: Krka, d. d., (krkg), Petrol, d. d., (petg), Telekom Slovenije, d. d., (tlsg), Mercator, d. d., (melr), Luka Koper, d. d., (lkpg), Gorenje, d. d., (grvg), Intereuropa, d. d., (iekg), Sava-Re, d. d., (posr) and Zavarovalnica Triglav, d. d., (zvtg). For the purposes of our research, the company had to increase their dividend a least once between 2008 and 2012. For that reason, Pozavarovalnica Sava (Sava-Re, d. d.), Intereuropa, d. d., in Luka Koper, d. d., were excluded from the research. So, for the company stock to be analysed, two conditions had to be met: a) company stocks are 
classified in the Slovenian stock index TOP; and b) in the period between 2008 and 2012, the management announced cash dividend increase at least once.

Finally, we analysed stock prices of 6 companies, which announced dividend increases 18-times in the observed period (Table 1). Following the example of Gupta et al. (2012), if the company management announces a dividend and this dividend was not paid out before, the event is handled as dividend increase. The dividend announced by the management is not necessary an actually paid-out dividend. Before the general meeting, an opposite proposal may be delivered, which is discussed at the meeting, and if the opposite proposal is adopted, the actually paid-out dividend may differ from the one proposed by the management. For the purposes of our research, following the sample of Gurgul, Mestel \& Schleicher (2003), we observed the dividend announced by the management, because the management has the best information on the situation in the company and the company operations, and the subject of our discussion is whether the management's signal on dividend increase to shareholders has a positive influence on company stock prices.

Table 1: The amount of announced dividends of companies from the SBI TOP index 2008 to 2012

\begin{tabular}{lccccc}
\hline Company & \multicolumn{5}{c}{ Dividend proposed by management (in EUR) } \\
\hline & 2008 & 2009 & 2010 & 2011 & 2012 \\
Krka, d.d. & $\mathbf{1 , 0 5}$ & $\mathbf{1 , 1}$ & $\mathbf{1 , 4}$ & $\mathbf{1 , 5}$ & $\mathbf{1 , 6 1}$ \\
Gorenje, d.d. & $\mathbf{0 , 4 5}$ & $/$ & $/$ & $/$ & $\mathbf{0 , 1 5}$ \\
Mercator, d.d. & $\mathbf{4 , 2 5}$ & $\mathbf{4 , 5}$ & $\mathbf{7 , 2}$ & $\mathbf{8}$ & 6 \\
Petrol, d.d. & 5,9 & 5,9 & 5,9 & $\mathbf{7 , 5}$ & $\mathbf{8 , 2 5}$ \\
Zavarovalnica Triglav, & 0,25 & 0,1 & $/$ & $\mathbf{0 , 4}$ & $\mathbf{0 , 5 5}$ \\
d.d. & 12,8 & 6 & 3 & $\mathbf{3}$ & $\mathbf{5}+\mathbf{3 , 7}$ \\
Telekom, d.d. & & & & & \\
\hline
\end{tabular}

Throughout the observed period, Krka, d. d., increased dividends in every year and this makes it the only such stock in the SBI TOP index. The value proposed by the management was then also confirmed by the general meeting. From 2007 to 2008, Gorenje, d. d., increased dividend, but failed to pay it out by 2011 due to poor business results and losses. In 2012, the management again proposed dividend pay-out. As we defined earlier, for the purposes of the research, the newly-proposed dividend is handled as dividend increase. In the period between 2008 and 2011, the company Mercator, d. d., increased dividend, but in 2012 dividend was lower than the one the year before, so it was excluded from the final sample. Between 2008 and 2010, the management of Petrol announced no dividend increase, so the sample includes only 2011 and 2012, when the management proposed dividend to increase again. In 2008, dividend of Zavarovalnica Triglav, d. d., decreased, likewise in 2009, but in 2010 it was not paid-out. So, the sample only includes 2011 and 2012. In 2008, the management of Telekom, d. d., announced dividend increase, in 2009 they announced dividend decrease, and then the 
announced dividend remained unchanged for two years. In 2011 and 2012, the company announced dividend increase, and then at the end of 2012 announced payment of interim dividend, which is for the purposes of the research also handled as dividend increase. It's worth noting here that proposed dividends are not necessarily paid-out.

The data on the dividend increase announcement date, and the data on stock quotes, were obtained from the portal of the Ljubljana Stock Exchange SEOnet and official websites of companies. For the purposes of the research, dividend increase announcement date is defined as the day on which the dividend announcement is officially made for the first time. Official announcement means posts on official websites of companies, the Ljubljana Stock exchange, or in printed media.

Announcements in various media, news may sometimes be announced only after the stock market closes. Also, it's practically impossible to check all sources, where the news on the management announcements could appear, and information may also appear in the market even before the first public announcement. For these reasons and in order to check whether the market efficiently reacts to announcements, the day of the first official announcement, following the example of Capstaff, Klaeboe \& Marshall (2004), was marked as $t=0$, and we also selected a 21-day time slot, which starts 10 days before the first official announcement and ends 10 days after. Time slot is therefore from $t=-10$ to $t=10$. The observed period is limited to the period between 2008 and 2012. The data for 2013, and the data available for 2014 are not analysed, because as of 1 January 2013 the new dividend-related tax arrangement entered into force, whereby dividend tax went up from the then $20 \%$ to $25 \%$, and the change may influence the results. In the sample of 18 dividend increases, there are 15 classic increases, where the dividend paid-out the year before was lower than in the current year, two newly-announced dividends (Gorenje, d. d., in 2012 and Zavarovalnica Triglav in 2011), and one interim dividend, which was paid-out by Telekom, d.d., in 2012. For the second part of the research, the sample of 18 announcements was divided to two groups. The first group includes 10 announcements in the years, when the SBI TOP index value dropped. The second group includes 8 announcements, when the SBI TOP ended the year higher than at the start of the year.

Applied methodology. To analyse the data, we applied the Event Study, which is used for the analysis of the effect of a certain event on stock price. The purpose of the event study is to find abnormal returns around the day of the event. With the market model we analysed the linear relationship between an individual stock and the SBI TOP index. We were determining to what extent the trend in stock of an individual company depends on entire market trend or trend in the SBI TOP index. The relationship between an individual stock and the index was analysed for 100 days before the beginning of the time slot $(t=-10, t=10)$, and namely by applying linear regression in the statistical analysis program SPSS. By obtained regression parameters, alfa and beta, we then predicted how the price of an individual stock would move within a time slot without the appearance of an abnormal event. Then, on the basis of the data on stock quotes we calculated the actual return of stock for the period within a time slot, and deducted from this the predicted return obtained earlier. Finally, by using t-test we had to check also statistical significance of obtained data. In the second part of the research we 
divided announcements to two groups, group 1 and group 2. In group 1 we analysed announcements from 2008, 2010 and 2011, and in group 2 we analysed announcement from 2009 and 2012. Announcements were put into groups on the basis of whether the SBITOP index dropped or grew in that calendar year. Daily abnormal returns for stock "i" within the time slot of 10 days before and 10 days after the announcement date (including the announcement date) were calculated by using the following formula (Gupta et al., 2012):

$$
A R_{i, t}=R_{i, t}-E\left(R_{i, t}\right)
$$

Where:

$\mathrm{t}=$ day according to the dividend increase announcement date $(\mathrm{t}=0)$.

$A R_{i, t}=$ abnormal return per stock " $\mathrm{i}$ " on day " $\mathrm{t}$ "

$R_{i, t}=$ actual return per stock " $\mathrm{i}$ ” on day " $\mathrm{t}$ ", which is calculated as:

$$
R_{i, t}=\frac{M P_{i, t}-M P_{i(t-1)}}{M P_{i(t-1)}}
$$

Where:

$M P_{i, t}=$ market stock price "i"on day " $\mathrm{t}$ "

$M P_{i(t-1)}=$ market stock price "i" on day " $\mathrm{t}-1$ "

In order to complete the calculation, we also have to define $E\left(R_{i, t}\right)$. This is the expected return of stock " $i$ " on day " $t$ ". Parameters of the equation are calculated by applying linear regression.

$$
E\left(R_{i, t}\right)=\alpha_{1}+\beta_{1} \times X
$$

Where:

$\alpha_{1}$ and $\beta_{1}$ are parameters obtained by linear regression, whereby stock returns 100 days before the start of the time slot were compared by index returns 100 days before the start of the time period.

$\mathrm{X}=$ actual returns of SBI TOP index, which are calculated in the same way as actual returns of individual stocks $\mathrm{R}_{\mathrm{i}, \mathrm{t}}$.

When we calculated all the required information, we started examining the statistical significance of obtained results. So, by applying the t-test, abnormal returns of all stocks on a specific day (such as, $\mathrm{t}=-10$ ) were compared with the average index return on that day. Average return of the SBI TOP index was calculated as follows:

$$
A R X_{i}=\frac{1}{N} \sum_{i=1}^{N} X_{i, t}
$$

where $\mathrm{N}=$ number of abnormal returns on a specific day 


\section{Research Results}

We wanted to determine whether dividend increase announcement has a statistically significant influence on stock prices within an observed time slot. If that's the case, we can confirm the presence of the signalling theory in the Slovenian stock market, otherwise we can refute it. Firstly, the expected return for every day was deducted from the actual return, and then we checked the statistical significance of results with the t-test. Table 2 shows calculations for the whole period. The sample includes 18 announcements, which occurred in the relevant period. The first column represents the observed time slot ten days before and ten days after the dividend increase announcement. In the second column we can see to what extent a stock dropped or grew in comparison to the to the expected growth or drop, which, according to the linear regression parameters, would happen irrespective of index trend. The third column contains the average return of the SBI TOP index on a specific day before, upon, or after the announcement. The fourth column shows results of the t-test, and the fifth column shows the results of statistical significance at the $5 \%$ confidence interval.

Table 2: Results of average abnormal return and t-test

\begin{tabular}{|c|c|c|c|c|}
\hline \multicolumn{2}{|r|}{$\mathbf{N}=\mathbf{1 8}$} & \multicolumn{3}{|c|}{ Market Model } \\
\hline Day & $\begin{array}{c}\text { Average Abnormal Return } \\
\text { (in \%) }\end{array}$ & $\begin{array}{l}\text { Average Stock Index Return } \\
\text { (in \%) }\end{array}$ & t-statistics & $\begin{array}{c}\text { sig } \\
(0,05)\end{array}$ \\
\hline-10 & 0,78338 & 0,137583 & 1,333 & 0,2 \\
\hline-9 & $-0,2564$ & 0,413702 & $-1,99$ & 0,063 \\
\hline-8 & $-0,3066$ & $-0,53414$ & 0,446 & 0,661 \\
\hline-7 & $-0,021$ & $-0,65372$ & 1,986 & 0,663 \\
\hline-6 & 0,37828 & $-0,47586$ & 2,357 & 0,031 \\
\hline-5 & 0,3634 & 0,084174 & 0,947 & 0,357 \\
\hline-4 & 0,11541 & 0,329035 & $-0,924$ & 0,369 \\
\hline-3 & 0,20239 & 0,712463 & $-1,711$ & 0,105 \\
\hline-2 & $-0,1811$ & 0,077347 & $-0,676$ & 0,508 \\
\hline-1 & 0,11425 & 0,174359 & $-0,107$ & 0,916 \\
\hline $\mathbf{0}$ & $-0,3762$ & 0,059322 & $-1,388$ & 0,183 \\
\hline $\mathbf{1}$ & 0,31869 & $-0,06133$ & 1,278 & 0,219 \\
\hline 2 & 0,0708 & 0,324623 & $-0,586$ & 0,566 \\
\hline 3 & $-0,2712$ & $-0,16594$ & $-0,355$ & 0,727 \\
\hline 4 & $-0,3173$ & $-0,3627$ & 0,178 & 0,861 \\
\hline 5 & $-0,124$ & 0,014272 & $-0,508$ & 0,618 \\
\hline 6 & $-0,3469$ & 0,021663 & $-0,781$ & 0,445 \\
\hline 7 & $-0,1924$ & $-0,57781$ & 1,459 & 0,163 \\
\hline 8 & 0,10517 & $-0,07515$ & 0,484 & 0,634 \\
\hline 9 & $-1,0391$ & $-0,35091$ & $-1,271$ & 0,221 \\
\hline 10 & $-0,1556$ & $-0,27685$ & 0,404 & 0,691 \\
\hline
\end{tabular}




\section{Macrothink}

As can be seen from the results, if we take into account all 18 announcements in the period between 2008 and 2012, and if we compare abnormal returns within a 21-day time slot with the average return of the SBI TOP index on those days, we do not get statistically significant results that could refute null hypothesis 1 . There were no days, except day six before the announcement, when we registered statistically significant increases in stock prices. Not only that, in 12 out of 21 days, the returns, according to the expected return calculated by means of index trend, were actually negative. Only on day six before the announcement, the analysis showed statistically significant increase in stock prices at the 5\% confidence interval. If we set the confidence interval more rigidly, at $1 \%$, there are no statistically significant unexpected returns on that day. This makes abnormal returns on dlay six before the announcement only an accidental event and they have no useful value.

After the analysis of results, we can conclude that the dividend signalling theory in the Slovenian market in the observed period does not hold and to investors the management's dividend increase announcement does not deliver any important new information on future operations, on the basis of which they would raise demand for stocks of a specific company. The null hypothesis 1 is not rejected.

In the second part we decided to carry out a research for two more separate periods. In first group we included the years, in which the SBI TOP index dropped, this means that index value at the end of the calendar year was lower than at the beginning of the year. The second group includes dividend increase announcements from 2009 and 2012, i.e. from the years in which the SBI TOP index ended the year higher that at the start of the year it. Figure 1 shows index trend in the period between 2008 and 2012, division by calendar years, and classification of individual years into two groups described earlier.

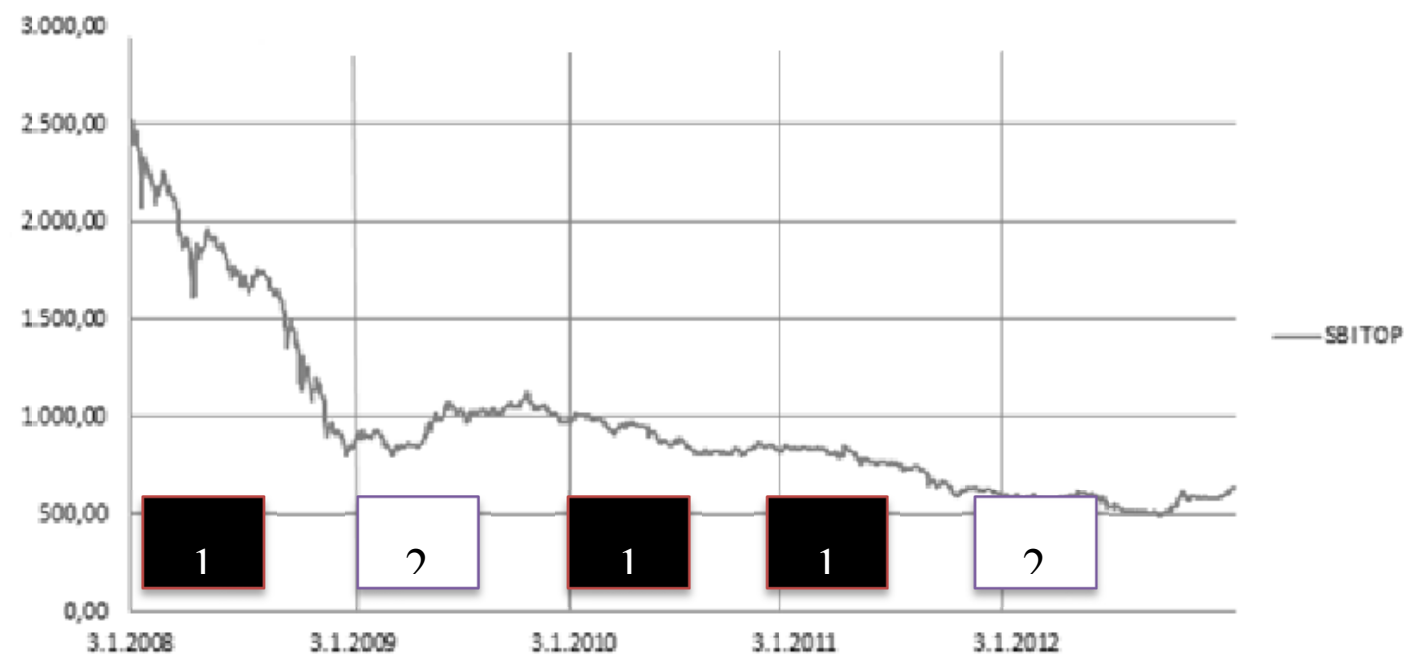

Figure 1: SBI TOP index movements in the period between 2008 and 2012 


\section{Macrothink}

The first group, which is marked with number 1 in the graph, included years 2008, 2010 and 2011. The year 2008 was the most specific year, because the index dropped by almost $70 \%$, which is a precedence in the Slovenian market. In 2009, the index slightly bounced back, but it has been dropping again for two and a half years, when it reached the lowest point in the second half of 2012. The second group, which is marked with number 2 in the graph, included years 2009 and 2012. Even though we can hardly speak of any relevant index growth here, its value at the end of the calendar year was still higher than at the start of the year. By dividing the years of the observed period into two groups, we wanted to find out whether dividend increase announcements have higher influence on stock price in the years, when atmosphere in the market is rather pessimistic, and whether there are any statistically significant abnormal returns in that period.

Results - group 1

Table 3-1: Results of average abnormal return and t-test for group 1

\begin{tabular}{|c|c|c|c|c|}
\hline \multicolumn{2}{|r|}{$\mathbf{N}=\mathbf{1 8}$} & & \multicolumn{2}{|c|}{ Market Model } \\
\hline Day & $\begin{array}{l}\text { Average Abnormal Return } \\
\text { (in \%) }\end{array}$ & $\begin{array}{c}\text { Average Stock Index Return } \\
\text { (in \%) }\end{array}$ & t-statistics & $\begin{array}{c}\text { sig } \\
(0,05)\end{array}$ \\
\hline-10 & 0,80503 & 0,073322 & 0,982 & 0,352 \\
\hline-9 & $-0,31531$ & 0,256423 & $-1,695$ & 0,124 \\
\hline-8 & $-0,03855$ & $-0,83154$ & 3,104 & $\mathbf{0 , 0 1 3}$ \\
\hline-7 & $-0,30456$ & $-1,05876$ & 1,609 & 0,142 \\
\hline-6 & 0,233798 & $-0,7939$ & 2,502 & $\mathbf{0 , 0 3 4}$ \\
\hline-5 & 0,83953 & $-0,08065$ & 2,459 & $\mathbf{0 , 0 3 6}$ \\
\hline-4 & 0,432303 & 0,657691 & $-0,784$ & 0,453 \\
\hline-3 & $-0,07317$ & 1,135165 & $-4,06$ & $\underline{0,003}$ \\
\hline-2 & $-0,32338$ & 0,259178 & $-1,468$ & 0,176 \\
\hline-1 & $-0,43104$ & 0,224046 & $-1,597$ & 0,145 \\
\hline $\mathbf{0}$ & 0,200032 & 0,245697 & $-0,249$ & 0,809 \\
\hline 1 & 0,432515 & $-0,22573$ & 2,117 & 0,063 \\
\hline 2 & 0,767093 & $-0,02014$ & 2,3 & 0,047 \\
\hline 3 & $-0,41469$ & $-0,24365$ & $-0,436$ & 0,673 \\
\hline 4 & 0,231342 & $-0,6663$ & 4,677 & 0,001 \\
\hline 5 & $-0,1471$ & $-0,05478$ & $-0,284$ & 0,783 \\
\hline 6 & $-0,02322$ & $-0,06094$ & 0,097 & 0,925 \\
\hline 7 & $-0,30406$ & $-0,14055$ & $-0,564$ & 0,587 \\
\hline 8 & $-0,45853$ & $-0,12312$ & $-1,128$ & 0,289 \\
\hline 9 & 0,175692 & $-0,39406$ & 2,206 & 0,055 \\
\hline 10 & $-0,24322$ & $-0,35953$ & 0,266 & 0,796 \\
\hline
\end{tabular}




\section{Mll Macrothink}

The results in table 3 for the years, in which the SBI TOP index dropped, deliver certain changes regarding the results throughout the observed period. On days 8, 6 and 5 before the announcement, stock prices grew or dropped statistically significantly less than the index. In table 2, we did not establish any statistically significant stock price increase in the days before the announcement. Increases in days before the announcement could mean that some investors have access to inside information. A more probable explanation is that due to the small size of market there is also a low number of events and thus individual values have a higher impact on the results. The results are also very close to the limit $95 \%$ confidence interval. This could also explain the results for day 3 before the announcement, when we recorded statistically significant drop in stock prices. Day 1, 2 and 4 after the announcement, stock prices grew. On day 1 they are very close to the $95 \%$ confidence interval, while on day 2 and 4 they are within the $95 \%$ confidence interval. On day 3, we recorded drop in stock prices, but it is not statistically significant. However, the results indicate that in the given years, on days after the announcement, some positive movements of stock prices can be seen, but the results are not convincing enough to be able to talk about the efficiency of the signalling theory in the Slovenian market within the years of general stock price falling and about the fact in that period investors are much more inclined to dividend payments. The condition set by McClusky et al. has not been met, because statistically significant increases are not concentrated sufficiently around the dividend increase announcement date. Therefore, null hypothesis 2 can also be confirmed. During the SBI TOP index drop period, shareholders still generate somewhat more purchase pressure on the stock of companies, whose managements announced dividend increase. Dividend increase in the challenging times on the stock exchange should make sure that the stock price does not slide under a specific threshold, particularly, if the dividend will not be go down in the following years. Also, dividend payment delivers a certain return and reduced cumulative loss. On the long term, in particular, dividends indicate an important share in overall profit.

The results from 2009 and 2012 did not show any statistically significant increases in stock prices. The results show that higher increases in stocks were registered in the years, when the market was on the downturn. The table 4 has only two statistically significant pieces of information, i.e. statistically significant drops in stock prices on day 4 and day 9 after the announcement. These two results, for the purposes of our research, do not provide any relevant information, and may be a result of the fact that a small and shallow market contributes to biased results. In the second part of our research, we divided announcements to two groups and found that dividend increase announcement had a higher influence on the stock price in years, when the SBI TOP dropped, than in the years, when the SBI TOP index grew. Despite the division to two groups, we still cannot confirm the dividend signalling theory in the Slovenian market, not in the period, when the index was dropping, and even less so in the index growth period. The results are similar to those for the entire period between 2008 and 2012, and refute the dividend signalling theory in the observed period and, consequently, the theory that dividends provide the investors with new information on the current and future situation in the company. 
Results - group 2

Table 3-2: Results of average abnormal return and t-test for group 2

\begin{tabular}{|c|c|c|c|c|}
\hline \multicolumn{2}{|r|}{$\mathrm{N}=18$} & \multicolumn{3}{|c|}{ Market Model } \\
\hline Day & $\begin{array}{c}\text { Average Abnormal Return } \\
\text { (in \%) }\end{array}$ & $\begin{array}{l}\text { Average Stock Index Return } \\
\text { (in \%) }\end{array}$ & t-statistics & $\begin{array}{c}\text { sig } \\
(0,05)\end{array}$ \\
\hline-10 & 0,756321 & 0,217909 & 0,863 & 0,417 \\
\hline-9 & $-0,18285$ & 0,610302 & $-1,202$ & 0,269 \\
\hline-8 & $-0,64175$ & $-0,16239$ & $-0,422$ & 0,686 \\
\hline-7 & 0,333365 & $-0,14742$ & 1,17 & 0,28 \\
\hline-6 & 0,558889 & $-0,07831$ & 0,963 & 0,368 \\
\hline-5 & $-0,23177$ & 0,2902 & $-1,308$ & 0,232 \\
\hline-4 & $-0,2807$ & $-0,08179$ & $-0,576$ & 0,582 \\
\hline-3 & 0,546833 & 0,184085 & 0,649 & 0,537 \\
\hline-2 & $-0,00334$ & $-0,14994$ & 0,2 & 0,847 \\
\hline-1 & 0,795863 & 0,11225 & 0,594 & 0,571 \\
\hline $\mathbf{0}$ & $-1,09654$ & $-0,17365$ & $-1,559$ & 0,163 \\
\hline $\mathbf{1}$ & 0,1764 & 0,144175 & 0,057 & 0,956 \\
\hline 2 & $-0,79956$ & 0,755584 & $-1,941$ & 0,093 \\
\hline 3 & $-0,09195$ & $-0,0688$ & $-0,049$ & 0,962 \\
\hline 4 & $-1,00312$ & 0,016803 & $-2,428$ & $\underline{0,046}$ \\
\hline 5 & $-0,0952$ & 0,10059 & $-0,404$ & 0,698 \\
\hline 6 & $-0,75144$ & 0,124915 & $-0,907$ & 0,394 \\
\hline 7 & $-0,05279$ & $-1,12437$ & 2,182 & 0,065 \\
\hline 8 & 0,809792 & $-0,01518$ & 1,181 & 0,276 \\
\hline 9 & $-2,55767$ & $-0,29698$ & $-2,382$ & $\underline{0,049}$ \\
\hline 10 & $-0,04614$ & $-0,17351$ & 0,3 & 0,773 \\
\hline
\end{tabular}

As can be gathered from analysed articles, in the majority of foreign markets, management's dividend increase announcements have a statistically significant positive influence on stock prices. This applies both to developing and developed markets. Obviously, the small size and illiquidity of the Slovenian stock market are specific, and the trend in stock prices does not follow the patterns, which apply to the great majority of other markets.

\section{Concluding Observations}

Every company management should follow the objective of maximizing the value of shareholders' assets, in general terms and as regards the decision on appropriate dividend policy, but when choosing a dividend policy the management is probably faced with a challenging task, because there is no universally adopted theory in this area. Three basic theories contradict each other, and the derived theories, like the name implies, mostly originate from the basic theories. In the same way, the signalling theory roughly supports the 
bird-in-the-hand theory, but it explains this influence in a different way. Namely, it is based on the assumption that there is asymmetry of information between the company management and investors. The management should have better information about the situation in the company and should give such information to investors through applying the dividend policy. The signalling theory or the influence of higher dividend announcement on the stock price of the company was the subject of many researches. The majority of researches confirmed the presence of the signalling theory. We decided to carry out the research in the Slovenian stock market by following an example of other authors, with certain adjustments. We were interested in how stock prices react to dividend increase announcements in Slovenia and whether they follow the pattern of trend in the developed markets. For the analysis, we choose the stocks of the Slovenian stock index SBI TOP and analysed them in the period between 2008 and 2012. Because we were interested in whether the management gives investors a signal on business operations by dividend increase, we observed the reactions on the proposed increase by the management, and not the dividends, which were then actually passed in the vote at the general meeting. Due to possible deviations around the announcement date, next to the announcement date we also observed the reactions in stock prices 10 days before and 10 days after the increase announcement. The research was also carried out for two separate groups, whereby we divided announcements according to whether they happened in the years, when the SBI TOP went up or down. The results for the entire Slovenian market did not shows enough statistically significant abnormal returns within a time slot, which means that the signalling theory in the Slovenian market, as opposed to the majority of foreign markets, does not hold. Null hypothesis 1, in which we claimed that dividend increase announcement has no statistically significant influence on stock prices, thus cannot be rejected. Separate results for group 1, which included announcements from the years, when the SBI TOP index went down, and the results for group 2 with the announcements from the years, when the SBI Top index went up, also did not deliver any different conclusion. The signalling theory in the Slovenian market does not hold, even if we discuss periods of market decline and growth separately. Null hypothesis 2 also cannot be rejected. Even though there were not enough statistically significant abnormal returns during the index decline period to be able to confirm the signalling theory, there were certain deviations according to the periods, when the index grew. On some days before the announcement and just after it, statistically significant abnormal returns were determined for group 1, which still indicates that in the period of market decline shareholders reacted more positively to the news. Some authors describe dividends in the period of market decline as a safety cushion from major losses, because they keep the stock price above a specific level and reduce cumulative loss through the dividend yield. Because of the dynamics of financial and stock markets, the results of our research are limited to the period, for which the research was carried out. So, we leave enough room for the research to be repeated and accept the possibility there may be different results in another observed period, and we suggest to possible interested parties to carry out the research again in a few years. We believe that the prices of Slovenian stocks in the second half of 2012 reached a multi-annual minimum and that the situation will improve in the years to come. This will result in greater market 
liquidity and the market will probably be more efficient. Perhaps the results obtained in the future period will be different from the current ones.

\section{References}

Akbar, M., \& Baig, H. H. (2010). The Reaction of Stock Prices to Dividend Announcements and Market Efficiency in Pakistan. The Lahore Journal of Economics, 15(1), 103-125.

Baker, H., \& Phillips, A. L. (1993). Why companies issue stock dividends. Financial Practice \& Education, 3(2), 29-37.

Bechmann. K. L., \& Raaballe, J. (2007). The differences between stock splits and stock dividends: Evidence on the retained earnings hypothesis. Journal of Business, Finance \& Accounting, 34(3\&4), 574-604. http://dx.doi.org/10.1111/j.1468-5957.2007.02041.x

Ben Arab, M., Ben Sedrine, N., \& Karaa, A. (2004). Shareholder Reaction to Dividend Announcements in an Emerging Market: Evidence from the Tunisian Stock Exchange. Finance India, 18(3), 1295-1314.

Brigham, E. F., \& Ehrhardt, M. C. (2002). Financial Management Theory and Practise. London: South-Western Thomson Learning, 699.

Capstaff, J., Klaeboe, A., \& Marshall, A. P. (2004). Share Price Reaction to Dividend Announcements: Empirical Evidence on the Signaling Model from the Oslo Stock Exchange. Multinational Finance Journal, 8(1\&2), 115-139. http://dx.doi.org/10.17578/8-1/2-4

Chawla, G. (2008). Dividend Policy Decisions. The Journal of American Academy of Business, Cambridge, 14(1), 42-47.

Grinblatt, M., Masulis R., \& Titman, S. (1984). The valuation effects of stock splits and stock dividends. Journal of Financial Economics, 13(4), 461-490. http://dx.doi.org/10.1016/0304-405x(84)90011-4

Gupta, S., Dogra, B., Vashisht, A. K., \& Ghai, S. (2012). Stock Price Reaction to Dividend Announcements. International Journal of Financial Management, 2(2), 23-31.

Gurgul, H., Mestel, R., \& Schleicher, C. (2003). Stock Market Reactions to Dividend Announcements: Empirical Evidence from the Austrian Stock Market. Swiss Society for Fin Mkts Portfolio Mgmt, 17(3), 332-350. http://dx.doi.org/10.1007/s11408-003-0304-1

Leland, H., \& Pyle D. (1977). Informational asymmetries, financial structure, and financial intermediation. Journal of Finance, 32(2), 371-387. http://dx.doi.org/10.2307/2326770

McClusky, T., Burton B.M., Power, D.M., \& Sinclair, C.D. (2006). Evidence on the Irish stock market's reaction to dividend announcements. Applied Financial Economics, (16), 617-628. http://dx.doi.org/10.1080/09603100600639058

Michaely, R., Thaler, R.H., \& Woach, K.L. (1995). Price reaction to dividend initiations and 
omissions: overreaction or drift? Journal of Finance, 50(2), 573-608. http://dx.doi.org/10.1111/j.1540-6261.1995.tb04796.x

Rankine, G. W., \& Stice, E. (1997). Accounting rules and the signalling properties of 20 percent stock dividends. Accounting Review, 72(1), 23-46.

Ross, S. (1977). The determination of financial structure: The incentive-signalling approach. Bell Journal of Economics, 8(1), 23-40. http://dx.doi.org/10.2307/3003485

Taneem, S., \& Yuce, A. (2011). Information Content of Dividend Announcements: An Investigation Of The Indian Stock Market. The International Business \& Economics Research Journal, 10(5), 49.

Wang, X., Manry, D., \& Wandler, S. (2011). Stock Dividend Policy in China. Journal of Global Business Management, 7(2), 1-9.

\section{Sources}

Annual Reports Gorenje d.d. [http://www.gorenjegroup.com/si/za-vlagatelje/letna-porocila].

Annual Reports Intereuropa

d.d.[http://www.intereuropa.si/index.php?page=reports\&item=13].

Annual Reports Krka d.d. [http://www.krka.si/sl/za-vlagatelje/financna-porocila/].

Annual Reports Luka Koper d.d. [http://www.luka-kp.si/slo/za-vlagatelje/poslovna-porocila].

Annual Reports Mercator d.d.

[http://www.mercatorgroup.si/sl/za-vlagatelje/porocila/nov-novica-2].

Annual Reports Petrol d.d.

[http://www.petrol.si/o-podjetju/za-vlagatelje/letna-porocila-dokumenti-druzbe].

Annual Reports Sava-Re d.d.

[http://www.sava-re.si/si/vlagatelji/financne-informacije/financna-porocila/].

Annual Reports Telekom Slovenije d.d.

[http://www.telekom.si/o-podjetju/za-vlagatelje/informacije-o-poslovanju/financna-porocila].

Annual Reports Zavarovalnica Triglav d.d.

[http://www.triglav.eu/sl/odnosi_z_vlagatelji/porocila_in_objave/financna_porocila].

Ljubljanska borza.stock exchange (2014). Arhiv vrednosti VP in indeksov.:

[http://www.ljse.si/cgi-bin/jve.cgi?doc=1289].

SEOnet. (2014). Portal Ljubljanske borze SEOnet -[http://seonet.ljse.si/default_sl.aspx].

\section{Copyright Disclaimer}

Copyright for this article is retained by the author(s), with first publication rights granted to the journal.

This is an open-access article distributed under the terms and conditions of the Creative Commons Attribution license (http://creativecommons.org/licenses/by/3.0/). 